\title{
Trichoderma oligosaccharides priming mediates resistance responses in pearl millet against downy mildew pathogen
}

\author{
Boregowda Nandini ${ }^{1}$, Puttaswamy Hariprasad ${ }^{2}$, Harischandra Sripathy Prakash ${ }^{1}$, Nagaraja Geetha ${ }^{1 *}$ \\ ${ }^{1}$ Department of Studies in Biotechnology, University of Mysore, Manasagangotri, Mysuru - 570 006, Karnataka, India \\ ${ }^{2}$ Centre for Rural Development and Technology Indian Institute of Technology, HauzKhas, New Delhi 110016, India.
}

\section{ARTICLE INFO}

Article history:

Received on: $12 / 12 / 2016$

Accepted on: 14/01/2017

Available online: 20/03/2017

Key words:

Trichoderma spp.,

Oligosaccharides, Sclerospora

graminicola, mannitol,

osmopriming, defense enzymes.

\begin{abstract}
Fungal cell wall oligosaccharides are being focused on the biological management of crop diseases by elicitation of defense responses. In the present study, an approach was taken to enhance the pearl millet disease resistance using biotic elicitors for eco-friendly management against downy mildew pathogen through seed priming approach. Crude oligosaccharides extracted from four different Trichoderma spp. enhances the disease protection ability in pearl millet. Seed priming with T. asperellum along with the osmopriming agent, mannitol had shown better protection with improved seedling vigor compared to controls. Modulation of defensive enzymes such as peroxidase and lipoxygenase also confirms the elicitation of resistance responses in the host with increased enzyme activity at different time interval patterns.
\end{abstract}

\section{INTRODUCTION}

Pearl millet [Pennisetum glaucum (L.) R.Br.] (PM) crop production is severely hampered by several biotic stresses. Downy mildew (DM) disease caused by the oomycete obligate pathogen, Sclerospora graminicola (Sacc.) Schroet. is one of the major biotic constraints. Downy mildew (DM) disease accounts for a yield loss of PM up to $20-40 \%$ annually [1]. The spread of DM disease is favored by high relative humidity (85-90\%) with moderate temperature $\left(20-30^{\circ} \mathrm{C}\right)$ [2]. Studies on plant-oomycete interactions are fundamental for research inventions as it gives a way ahead to develop economically with improved disease resistance crop against the pathogen $[3,4]$. The biological control mechanisms, such as antibiosis, antagonism, mycoparasitism and induction of plant defense responses have all been accredited in Trichoderma spp. [5]. Trichoderma and its direct interaction with plant pathogen involve cell-wall degrading substances including antibiotics attributes as important factors for mycoparasitism and antibiosis $[6,5,7,8]$. The production of the extracellular cellwall degrading enzymes such as chitinase, cellulase, protease and $\beta$ - $(1,3)$ glucanase by Trichoderma spp. have a vital role in the inhibition of the fungal pathogens and induced resistance of host

* Corresponding Author

Email: eetha@appbot.uni-mysore.ac.in plant system [9, 10]. Earlier reports reveal the efficiency of Trichoderma spp. as biofertilizers/ biocontrol agents for crop production in the field or greenhouse agriculture farming systems $[5,11]$ as an alternative choice to the chemical fungicides [12]. Root colonization by the antagonist Trichoderma has been studied using conventional microbiological techniques [13]. The inhibitory activities of $T$. harzianum and $T$. viride culture filtrate against Fusarium moniliforme was due to the production of volatile compounds and release of extracellular enzymes, such as those with amylolytic, pectinolytic, proteolytic and cellulolytic activities [14]. Oligomers of chitin and glucan are fungal elicitors generated from fungal cell walls and are measured as primary signals responsible for the initiation of plant resistance reactions [18]. Chitosan (poly-(1,4)- $\beta$-D-glucosamine) is known to induce systemic resistance in PM and defends through the establishment of defense responses [15,16]. Trichoderma-derived cell wall degrading enzymes and fungal metabolites from $T$. asperellum CCTCC-RW0014 have a synergistic inhibitory effect to control fungal pathogen Fusarium oxysporum f. sp. cucumerinum [17]. It is well-known that several oligosaccharides from fungal cell wall components stimulate phytoalexin secretion and lignin or callose formation in plants $[19,20]$. The present work was aimed to study the possible effects of crude oligosaccharides from Trichoderma spp. on PM seed quality parameters and its ability to induce resistance in PM against DM pathogen. 


\section{MATERIALS AND METHODS}

\subsection{Host and Pathogen}

Highly susceptible PM seeds to DM pathogen i.e., cv. 7042S were obtained from the International Crop Research Institute for Semi-Arid Tropics, Patencheru, India, under a material transfer agreement and were used throughout the study. Pearl millet (PM) seeds of cultivar 7042S, were surface sterilized with $0.2 \%$ sodium hypochlorite for $2 \mathrm{~min}$ and rinsed in distilled water for 2-3 times.

Downy mildew (DM) pathogen sick plot was maintained at the Department of Biotechnology, University of Mysore,

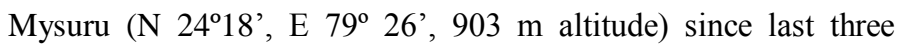
decades under the ICAR program, provided the source of $S$. graminicola. Infected leaves were collected in evenings, cleaned under running tap water, blot-dried and placed in a moist chamber at $20^{\circ} \mathrm{C}$ and $>95 \%$ relative humidity $(\mathrm{RH})$. Fresh sporangia formed on the leaves were collected in distilled water and the spore load was attuned to $4 \times 10^{4}$ zoospores $\mathrm{ml}^{-1}$ and further used as inoculum in various experiments.

\subsection{Extraction of oligosaccharides from Trichoderma spp.}

Trichoderma spp., namely $T$. asperellum, T. atroviride, $T$. longibrachiatum and T. brevicompactum were obtained from the department stock culture, which are basically isolated from the root rhizosphere soil sample of the monocot plants. The Trichoderma spp. was mass-multiplied on potato dextrose broth for 12-14 days at $28 \pm 2^{\circ} \mathrm{C}$. At the end of the incubation phase, mycelia were collected and dried at $60^{\circ} \mathrm{C}$ for $48 \mathrm{~h}$. Mycelium (100 g) was extorted overnight with acetone $\left(250 \mathrm{ml}\right.$ at $\left.20^{\circ} \mathrm{C}\right)$ and the powder was subjected to alkaline treatment consisting of $100 \mathrm{ml}$ of $0.1 \mathrm{M} \mathrm{NaOH}$ at $60^{\circ} \mathrm{C}$ for $2 \mathrm{~h}$. The supernatant was neutralized to $\mathrm{pH} 7$ with $50 \%$ acetic acid and stored overnight at $4^{\circ} \mathrm{C}$. The resultant sample was centrifuged $\left(16,500 \mathrm{~g}, 20 \mathrm{~min}\right.$ at $\left.20^{\circ} \mathrm{C}\right)$ and the supernatant was collected and lyophilized [21]. The presence of oligosaccharides in the samples was confirmed by Molisch test [22] and reducing sugars were estimated by phenol-sulfuric acid method [23].

\subsection{Effect of seed priming with Trichoderma oligosaccharides on PM seed quality parameters}

Pearl millet seeds cv. $7042 \mathrm{~S}$ were treated with crude oligosaccharide extracts alone and also along with $1 \%$ mannitol as a priming agent in the same concentration of oligosaccharides in $0.5,1,2,4,6$, and $8 \mathrm{mg} / \mathrm{ml}$ for $12 \mathrm{~h}$ at room temperature on a shaker at $150 \mathrm{rpm}$. Distilled water and $1 \%$ mannitol treatment served as controls [24, 25]. Germination test was performed by the paper towel method according to the standard measures of International Seed Testing Association [26]. Seedling vigor was evaluated by following the method of Abdul Baki and Anderson [27]. Four samples of 100 seeds for each treatment were used and the experiment was replicated thrice. The vigor index (VI) was calculated using the formula:

$\mathrm{VI}=($ mean root length + mean shoot length $) \times$ percentage of germination
2.4 Effect of seed priming with Trichoderma oligosaccharides on PM-DM disease response under greenhouse conditions

In the greenhouse study, primed seeds were sown in pots containing sterilized soil: decomposed cow dung manure $(3: 1 \mathrm{v} / \mathrm{v})$. Seed priming was performed as described earlier. Seeds treated with the metalaxyl at $6 \mathrm{~g} / \mathrm{kg}$ dose served as a positive control treatment. A randomized complete block design was laid out for the experiment. Zoospore suspension of $S$. graminicola was whorlly challenge-inoculated for two-day-old seedlings at a concentration of $4 \times 10^{4}$ zoospores $\mathrm{ml}^{-1}$ [28]. Under greenhouse conditions, the challenge-inoculated plants were maintained (90$95 \% \mathrm{RH}, 20-25^{\circ} \mathrm{C}$ temperature). Each treatment consists of eight replications of five pots with eight seedlings each and repeated thrice.

Disease incidence was observed by recording the number of plants that showed typical DM symptoms like, sporulation on the abaxial leaf surface, stunted growth, chlorosis, or malformation of the panicles. The experiment was concluded 60 days after sowing.

\subsection{Defense-related enzyme analysis}

Seedlings were grown on wet blotter discs in petriplates (25 seeds/plate). Three-day-old seedlings were inoculated with a zoospore suspension of $4 \times 10^{4} \mathrm{ml}^{-1}$ by root-dip method and incubated in the dark at $25( \pm 1){ }^{\circ} \mathrm{C}$ [29]. Seedlings $(1 \mathrm{~g}$ fresh weight) were collected in the different time interval at $0,6,12,18$, $24,30,36,42,48,60,72$, and $96 \mathrm{~h}$ after challenge pathogen inoculation and then grind to a fine powder in liquid nitrogen to extract enzymes and used for assays. The protein content was examined using the dye-binding method of Bradford [30] with bovine serum albumin (Sigma, USA) as standard.

\subsection{Peroxidase (POX) assay (EC 1.11.1.7)}

Seedlings (1g) extracted with $10 \mathrm{mM}$ potassium phosphate buffer (pH 6.9) and the supernatant was collected at $4{ }^{\circ} \mathrm{C}$ was used as enzyme source. Enzyme assay was performed as explained by Hammerschmidt et al. [31]. The reaction mixture (3 $\mathrm{ml}$ ) includes $0.25 \%(\mathrm{v} / \mathrm{v})$ guaiacol in $10 \mathrm{mM}$ potassium phosphate buffer (pH 6.9) containing $10 \mathrm{mM}$ hydrogen peroxide. Crude enzyme extract addition initiates the reaction and measured spectrophotometrically at $470 \mathrm{~nm}$ absorbance (Hitachi U-3900, Japan).

The variation in absorbance $\left(\Delta \mathrm{A}_{470}\right)$ was divided by the tetraguaiacol molar extinction coefficient $\left(26.6 \mathrm{mM}^{-1} \mathrm{~cm}^{-1}\right)$ and the enzyme activity expressed as $\mu \mathrm{mol}$ of $\mathrm{H}_{2} \mathrm{O}_{2} \mathrm{~min}^{-1} \mathrm{mg}^{-1}$ of protein [32]. The experiment was done thrice and average enzyme activity was recorded.

\subsection{Lipoxygenase (LOX) assay (EC 1.13.11.12)}

Lipoxygenase activity was examined by following the method of Borthakur et al. [33]. Enzyme source was obtained by grinding the $0.5 \mathrm{~g}$ seedlings extract with $5 \mathrm{ml}$ of $0.2 \mathrm{M}$ sodium phosphate buffer $(\mathrm{pH} 6.5)$ and a supernatant was collected as an enzyme source. The activity was measured spectrophotometrically 
by observing the occurrence of the conjugated diene hydroperoxide at $234 \mathrm{~nm}$. LOX assay substrate was prepared by following the procedure described by Axelrod et al. [34]. Linoleic acid $(28 \mathrm{mg}$ ) and an equal weight of Tween-20 plus $2 \mathrm{ml}$ of distilled water were added. An Appropriate amount $(50 \mu \mathrm{l})$ of $2 \mathrm{~N}$ $\mathrm{NaOH}$ was added to attain a clear solution. The solution was made up to $10 \mathrm{ml}$ with distilled water. Fresh substrate was prepared for each time and used for the enzyme assay. The reaction mixture consists $2.7 \mathrm{ml}$ of sodium phosphate buffer $(0.2 \mathrm{M}, \mathrm{pH} 6.5)$ and $0.3 \mathrm{ml}$ of substrate. The reaction was started by the addition of enzyme extract and the absorbance at $234 \mathrm{~nm}$ was noted for $3 \mathrm{~min}$ using Hitachi U-3900 spectrophotometer.

The difference in absorbance $\left(\Delta \mathrm{A}_{234}\right)$ was divided by the molar extinction coefficient $\left(23,000 \mathrm{M}^{-1} \mathrm{~cm}^{-1}\right)$ of hydroperoxide formed and the enzyme activity expressed as $\mu \mathrm{mol} \mathrm{min} \mathrm{mg}^{-1}$ protein. The experiment was done thrice and average enzyme activity was recorded.

\subsection{Statistical analysis}

Data from different treatments were evaluated for each experiment and subjected to arcsine transformation and analysis of variance using SPSS Inc. 17.0. Significant results of treatments were determined by $\mathrm{F}$ values $(P \leq 0.05)$. Average of the treatment was separated by Tukey's honestly significant differences (HSD) test.

\section{RESULTS}

\subsection{Effect of seed priming with Trichoderma-mediated oligosaccharides on seed germination parameters of PM}

Seed priming with crude oligosaccharides in different concentrations has not shown any inhibition parameters of seed germination and vigor. Though, there was no significant $(P \leq 0.05)$ variation observed in treated seedlings germination percentage, seedling vigor was enhanced significantly $(P \leq 0.05)$ in treated seedlings compared to the control treatments, in which, $T$. asperellum at $4 \mathrm{mg} / \mathrm{ml}$ with $1 \%$ mannitol had shown maximum germination percentage of $93 \%$ with seedling vigor of 1757 . Metalaxyl seed treatment shows $89 \%$ seed germination and 1591 seedling vigor and it not significantly $(P \leq 0.05)$ different from the distilled water control. Amongst the crude oligosaccharides treatment of Trichoderma spp., from $T$. longibrachiatum shows minimum efficacy in improving the seed germination and its vigor, which is not significantly different from the control treatments (Figure 1).

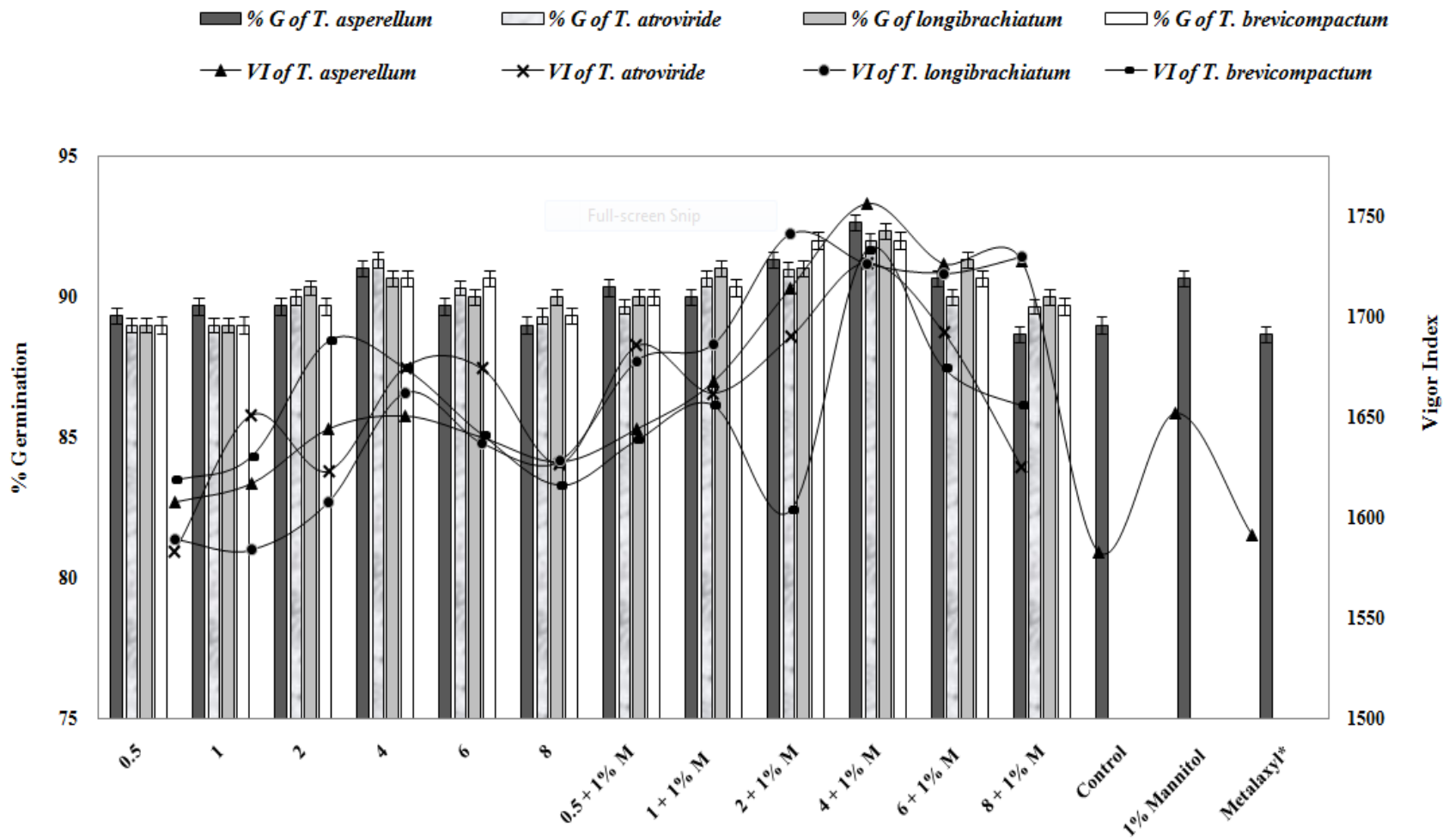

Concentration of oligosaccahrides $(\mathrm{mg} / \mathrm{ml})$

Fig. 1: Effect of seed priming with Trichoderma spp. mediated oligosaccharide extracts on seed germination and seedling vigor of pearl millet. Values are means of three independent replicates. $\% \mathrm{G}$ - percent germination; $\mathrm{SV}$ - seedling vigor. *Metalaxyl was used as seed dressing at of 6 g/kg seed. 
Table 1: Greenhouse experiments showing DM disease protection upon seed priming with Trichoderma-mediated oligosaccharides.

\begin{tabular}{|c|c|c|c|c|c|}
\hline Treatment & $\begin{array}{l}\text { Conc. } \\
\mathrm{mg} / \mathrm{ml}\end{array}$ & \multicolumn{4}{|c|}{ \% Downy mildew disease protection } \\
\hline \multirow{4}{*}{ Crude oligosaccharides } & 1 & $35.8 \pm 1.33^{\operatorname{lmno}}$ & $37.1 \pm 0.13^{\mathrm{mno}}$ & $29.8 \pm 1.44^{\text {opq }}$ & $33.1 \pm 1.25^{\text {nop }}$ \\
\hline & 2 & $47.0 \pm 1.17^{\mathrm{ggh}}$ & $46.5 \pm 0.44^{\mathrm{fgh}}$ & $31.7 \pm 0.81^{\text {lopq }}$ & $33.4 \pm 1.86^{\text {nop }}$ \\
\hline & 6 & $45.1 \pm 1.21^{\mathrm{ghi}}$ & $39.7 \pm 1.93^{\mathrm{klm}}$ & $36.7 \pm 1.86^{\mathrm{mno}}$ & $27.9 \pm 1.36^{\mathrm{opq}}$ \\
\hline & 8 & $33.1 \pm 1.25^{\mathrm{nop}}$ & $46.7 \pm 1.29^{\mathrm{fgh}}$ & $32.6 \pm 1.57^{\text {nop }}$ & $30.5 \pm 0.79^{\text {opq }}$ \\
\hline \multirow{4}{*}{$\begin{array}{c}\text { Crude oligosaccharides } \\
+1 \% \text { mannitol }\end{array}$} & 0.5 & $34.9 \pm 1.75^{\mathrm{mno}}$ & $31.9 \pm 0.84^{\mathrm{opq}}$ & $33.9 \pm 1.72^{\text {nop }}$ & $31.8 \pm 1.741^{\mathrm{opq}}$ \\
\hline & 4 & $61.7 \pm 0.80^{\mathrm{b}}$ & $54.9 \pm 1.86^{\mathrm{bcd}}$ & $34.0 \pm 1.56^{\text {nop }}$ & $42.0 \pm 2.2^{\mathrm{jkl}}$ \\
\hline & 6 & $50.4 \pm 1.82^{\text {cde }}$ & $44.9 \pm 1.86^{\mathrm{ghi}}$ & $42.6 \pm 1.57^{\mathrm{ijk}}$ & $37.7 \pm 1.11^{\mathrm{lmn}}$ \\
\hline & 8 & $47.0 \pm 1.12^{\mathrm{fgh}}$ & $48.2 \pm 0.52^{\mathrm{efg}}$ & $34.6 \pm 2.33^{\mathrm{mno}}$ & $35.0 \pm 2.58^{\mathrm{mno}}$ \\
\hline Control & - & - & & & \\
\hline $1 \%$ Mannitol & - & $21.4 \pm 0.59^{9}$ & & & \\
\hline Metalaxyl* & - & $90.5 \pm 0.71^{\mathrm{a}}$ & & & \\
\hline
\end{tabular}

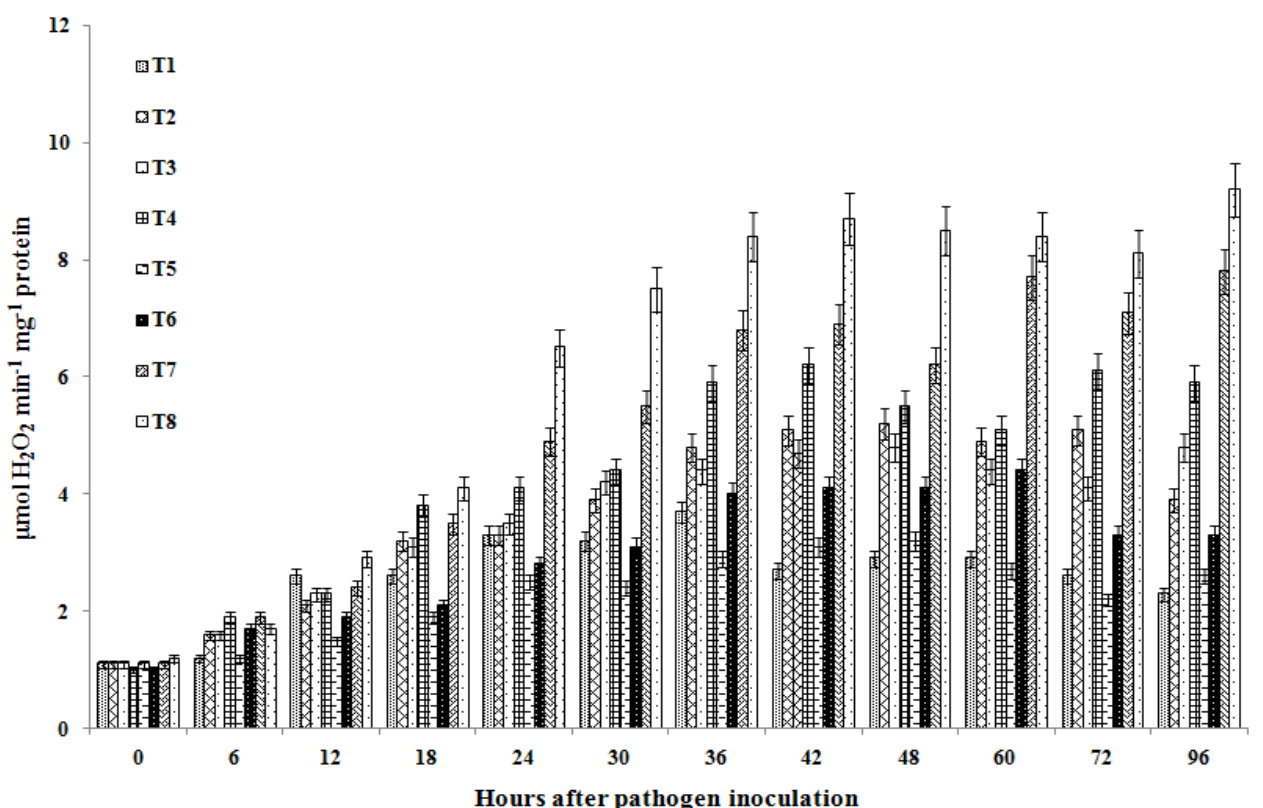

Fig. 2: Temporal profile of accumulation of peroxidase (POX) enzyme in pearl millet (PM) seedlings upon seed priming with oligosaccharide from $T$. asperellum. Lines on the bars indicate the standard error. T1 - control; T2 - 1\% mannitol; T3 - Seed priming with oligosaccharides of T. asperellum; T4 - Seed priming with oligosaccharides of T. asperellum $+1 \%$ mannitol; T5 - control + pathogen; T6 - 1\% mannitol + pathogen; T7 - Seed priming with oligosaccharides of T. asperellum + pathogen; T8 - Seed priming with oligosaccharides of T. asperellum $+1 \%$ mannitol + pathogen.

\subsection{Oligosaccharides stimulates resistance responses in PM against DM under greenhouse conditions}

Under greenhouse conditions, $T$. asperellum with mannitol $(1 \%)$ shows significant $(P \leq 0.05)$ protection compared to the other treatments. It was observed that mannitol (1\%) treatment alone had not shown any protection against DM pathogen. Further, when it is used in combination with crude oligosaccharide elicitors, it acts as a priming agent for seed treatment with elicitor, which will enhance protection ability of the treatment. $T$. asperellum (4 $\mathrm{mg} / \mathrm{ml})$ with $1 \%$ mannitol offers maximum protection with least disease incidence of $37.2 \%$ with $61.7 \%$ disease protection. However, positive control treatment, metalaxyl offers least disease incidence of $10.7 \%$ compared all other treatments (Table 1).

\subsection{Modulation in defense enzyme activities}

The temporal modulation changes in the defense enzyme activity of POX and LOX in treated and control seedlings with or without pathogen inoculation was illustrated in Figures 2 and 3. Besides, a constitutive level of POX and LOX enzyme activities was recorded in all the tested seedlings. In the case of $T$. asperellum treatment with $1 \%$ mannitol, POX and LOX enzyme activities were apparent at $0 \mathrm{~h}$, which steadily increased and attained highest at 42 and $96 \mathrm{~h}$ for POX and $48 \mathrm{~h}$ for LOX, at which the activity has been increased two folds higher than in control-inoculated seedlings (Figures 2 and 3). Distilled water treated control and $1 \%$ mannitol treatments showed least enzyme activities at all time intervals confirming the susceptibility of the selected cultivar to DM pathogen. 


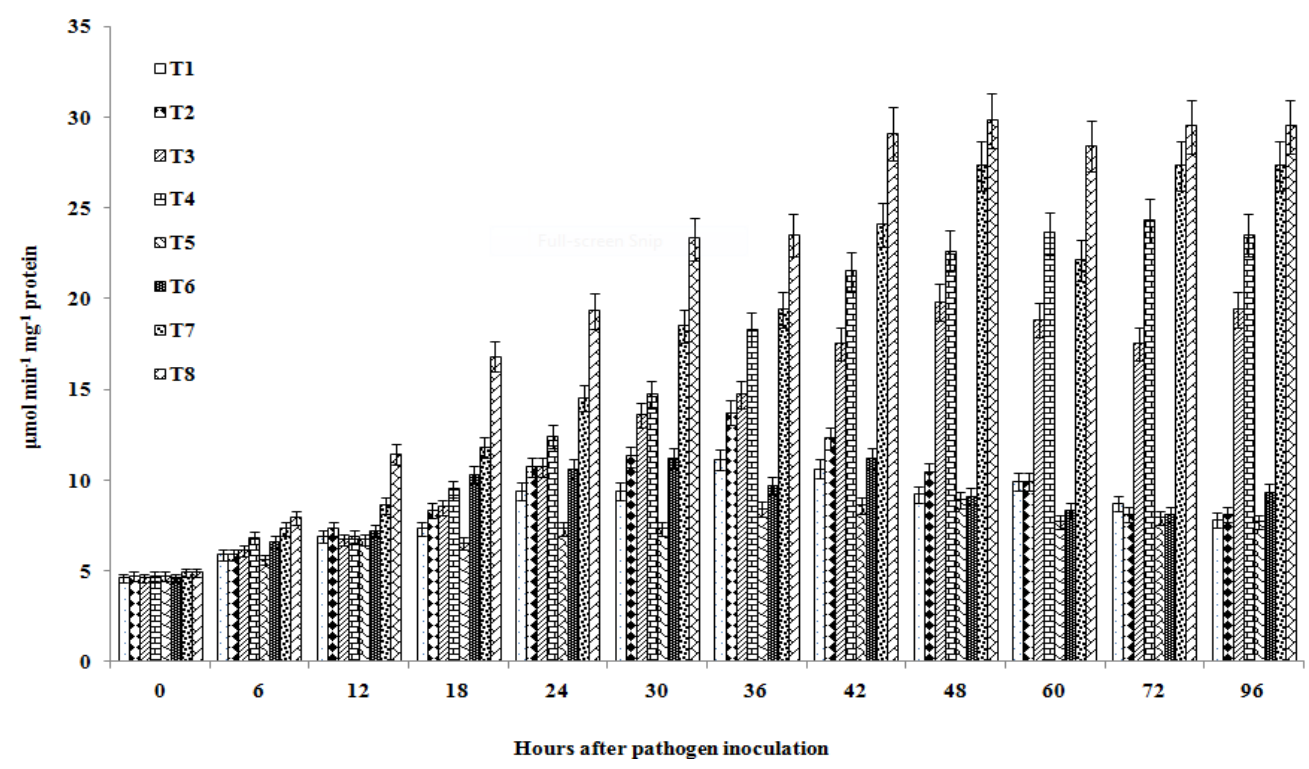

Fig. 3: Temporal profile of accumulation of lipoxygenase (LOX) enzyme in pearl millet (PM) seedlings upon seed priming with oligosaccharide from $T$. asperellum. Lines on the bars indicate the standard error. T1 - control; T2 - 1\% mannitol; T3 - Seed priming with oligosaccharides of T. asperellum; T4 - Seed priming with oligosaccharides of T. asperellum $+1 \%$ mannitol; T5 - control + pathogen; T6 - $1 \%$ mannitol + pathogen; T7 - Seed priming with oligosaccharides of T. asperellum + pathogen; T8 - Seed priming with oligosaccharides of T. asperellum $+1 \%$ mannitol + pathogen.

\section{DISCUSSION}

Plant-pathogen interactions are most essential aspect for minimizing the economic deficits caused by pathogens in crops [35]. In the present work, we examined the efficacy of the Trichoderma spp. crude oligosaccharides on the PM seed quality parameters and in inducing the DM disease protection ability. Furthermore, correlation pattern was observed in defense enzyme activities with disease protection studies under laboratory and green house conditions. Our earlier report illustrates the efficacy of Trichoderma spp. crude oligosaccharides in elicitation of defense responses in PM-DM interaction [25]. In comparison to earlier work, in which, T. virens along with $1 \%$ mannitol had shown higher defense enzyme activities compared other treatments along with significant disease protection $(P \leq 0.05)$. Mannitol acts as an osmopriming agent in combination with crude elicitors. Roopa et al. [24] illustrate the similar observation by osmopriming with mannitol enhancing the seed quality parameters and planting value in PM. As a sustained part of the our earlier work, in the present exertion, T. asperellum with $1 \%$ mannitol shows significant $(P \leq$ $0.05)$ protection with minimum disease incidence along with elevated defense enzyme accumulation till the time interval of 96 hours after pathogen inoculation. This study demonstrates the role a close relationship of Trichoderma spp. isolated from the monocot root rhizosphere samples is capable of protecting PM host by induction of DM disease resistance.

With mounting ecological attentiveness, the hub of controlling plant diseases has been changed in the direction of feasible and sustainable alternative approaches [36]. Trichoshield, a talc formulation consisting of spores of $T$. harzianum, $T$. lignorum, Gliocladium virens and Bacillus subtilis seed treatment has improved seed germination factors, vegetative and reproductive growth parameters and provide better protection against DM pathogen under field conditions compared to the individual isolates of T. harzianum, T. lignorum, G. virens and $B$. subtilis [37]. Biocontrol strain T. harzianum Th10 mediated cell wall glucan elicitor shows better glucanase activity and phenol accumulation in treated seedlings contrast to control seedlings [38]. Several reports on DM-PM interaction with significance to priming with elicitors have been done. Our present findings are also in concurrence with the findings enhanced levels of defenserelated enzymes observed in crude oligosaccharide treated PM seedlings and further increased after $S$. graminicola infection specifies that seed treatment of PM with oligosaccharides makes an incompatible atmosphere for infection, production and sporulation by $S$. graminicola which directs to the disease inhibition [39, 40, 41]. Oligosaccharides extracted from the cell wall of $T$. asperellum shows significantly $(P \leq 0.05)$ enhanced defense activity in PM plant and control the DM infection. Hence, this study puts effort to formulate different species of Trichoderma oligosaccharides isolated from monocot rhizhospheric zones and amalgamate into a biological treatment.

\section{CONCLUSION}

The present work throws an insight into the efficacy of Trichoderma spp. oligosaccharides extracted from the mycelium in improving the PM growth as well as in controlling the DM disease. Further, it confirms the osmopriming activity of the mannitol along with oligosaccharide combinations in improving the seedling vigor and enhancing the disease protection and 
thereby developing an efficient biological disease management approach to control the oomycete pathogen.

\section{Financial support and sponsorship: Nil.}

Conflict of Interests: There are no conflicts of interest.

\section{REFERENCES}

1. Thakur RP, Rao VP, Sharma R. Influence of dosage, storage time and temperature on efficacy of metalaxyl treated seed for the control of pearl millet downy mildew. Euro J Plant Pathol. 2011; 129:323059.

2. Thakur RP, Rai KN, Khairwal IS, Mahala RS. Strategy for downy mildew resistance breeding in pearl millet in India. J SAT AgricRes. 2008; 6:1-11.

3. Dodds PN, Rathjen JP. Plant immunity: towards an integrated view of plant-pathogen interactions. Nat Rev Genet. 2010; 11:53948.

4. Boyd LA, Ridout C, O'Sullivan DM, Leach JE, Leung H. Plantpathogen interactions: disease resistance in modern agriculture. Trends Genet. 2013; 29:233-240.

5. Harman GE, Howell CR, Viterbo A, Chet I, Lorito M. Trichoderma species- opportunistic a virulent plant symbionts, Nat. Rev. Microbiol. 2004; 2:43-56.

6. Benitez T, Rincon AM, Limon MC, Codon AC. Biocontrol mechanisms of Trichoderma strains. Int Microbiol. 2004; 7:249-260.

7. Sivasithamparam K, Ghisalberti EL. Secondary metabolism in Trichoderma and Gliocladium. In: Kubicek CP, Harman GE, editiors. Trichoderma and Gliocladium, Basic Biology, Taxonomy and Genetics, London: Taylor and Francis Ltd; 1998, p. 139-191.

8. Kredics L, Antal Z, Manczinger L, Nagy E. Breeding of mycoparasitic Trichoderma strains for heavy metal resistance. Lett Appl Microbiol. 2001; 2:112- 116.

9. Gajera HP, Bambharolia RP, Patel SV, Khatrani TJ, Goalkiya BA. Antagonism of Trichoderma spp. against Macrophomina phaseolina: evaluation of coiling and cell wall degrading enzymatic activities. J Plant Pathol Microb. 2012; 3:7.

10. Vinale F, Sivasithamparam K, Ghisalberti EL, Marra R, Woo SL, Lorito M. Trichoderma plant pathogen interactions. Soil Biol Biochem. 2008; 40:1-10.

11. Brunner K, Zeilinger S, Ciliento R, Woo S, Lorito M, Kubicek CP, Mach RL. Improvement of the fungal biocontrol agent Trichoderma atroviride to enhance both antagonism and induction of plant systemic disease resistance. Appl Environ Microbiol. 2005; 71:3959_ 3965.

12. Harman GE, Kubicek CP. Trichoderma and Gliocladium. Enzymes, biological control and commercial applications, UK London; Taylor and Francis. 1998; vol. 2

13. Ge barowska EW, Pietr SJ. Colonization of roots and growth stimulation of cucumber by iprodione-resistant isolates of Trichoderma spp. applied alone and combined with fungicides. Phytopathol Pol. 2006; 41:51-64.

14. Calistru C, McLean M, Berjak P. In Vitro Studies on the Potential for Biological Control of Aspergillus flavus and Fusarium moniliforme by Trichoderma Species: A Study of the Production of Extracellular Metabolites by Trichoderma Species. Mycopathologia 1997; 137:115-124.

15. Manjunatha G, Niranjan Raj S, Shetty NP, Shetty HS. Nitric oxide donor seed priming enhances defense responses and induces resistance against pearl millet downy mildew disease. Pestic Biochem Physiol 2008; 91:1-11.

16. Manjunatha G, Deepak S, Geetha NP, Niranjan-Raj S, Kini RK, Shetty HS. Hypersensitive reaction and P/HRGP accumulation is modulated by nitric oxide through hydrogen peroxide in pearl millet during Sclerospora graminicola infection. Physiol Mol Plant Pathol. 2009; 74:191-198
17. Saravanakumar K, Yu C, Dou K, Wang M, Li Y, Chen J. Synergistic effect of Trichoderma-derived antifungal metabolites and cell wall degrading enzymes on enhanced biocontrol of Fusarium oxysporum f. sp. Cucumerinum. Biol Control. 2016; 94:37-46

18. Lamb CJ, Lawton MA, Dron M. and Dixon RA. Signals and transduction mechanisms for activation of plant defense against microbial attack. Cell. 1989; 56:215-24.

19. Kauss H, Jeblick W, Domard A. The degrees of poylimerization and $\mathrm{N}$-acetylation of chitosan determine its ability to elicite callose formation in suspension cells and protoplasts of Catharanthus roseus. Planta. 1989; 178:385-392.

20. Lattanzio V, Lattanzio VMT, Cardinali A. Role of phenolics in the resistance mechanisms of plants against fungal pathogens and insects. Phytochem Adv Res. 2006; 6: 23- 67.

21. Nita-Lazar M, Heyraud A, Gey C, Braccini I, Lienart Y. Novel oligosaccharides isolated from Fusarium oxysporum L. rapidly induce PAL activity in Rubus cells. Acta Biochem Pol. 2004; $51: 625$ 34

22. Sadasivam S, Balasubramanian T. Practical manual (undergraduate). Coimbatore: Tamil Nadu Agricultural University. 1985; p. 2.

23. Dubois M, Gilles KA, Hamilton JK, Smith F. Colorimetric method for determination of sugars and related substances. Ann Chem. 1956; 28:350-6.

24. Roopa KS, Geetha NP, Sharathchandra RG, Pushpalatha HG, Sudisha J, Amruthesh KN, Prakash HS, Shetty HS. Osmopriming enhances pearl millet growth and induces downy mildew disease resistance. Arch Phytopathol Plant Prot. 2009; 42:979-87.

25. Nandini B, Hariprasad P, Niranjana SR, Shetty HS, Geetha NP. Elicitaion of resistance in pearl millet by oligosaccharides of Trichoderma spp. against downy mildew disease. J Plant Inter. 2013; 8:45-55.

26. International Seed Testing Association. 2003. Proceedings of ISTA International rules for seed testing. Seed Sci Technol. 21:25-30.

27. Abdul Baki AA, Anderson JD. Vigor determination in soybean seed by multiple criteria. Crop Sci. 1973; 13:630-3.

28. Singh SD, Gopinath R. A seedling inoculation technique for detecting downy mildew resistance in pearl millet. Plant Dis. 1985; 72:425-8.

29. Safeeulla KM. Biology and control of the downy mildews of pearl millet, sorghum and finger millet. Biol Control downy mildews pearl millet, sorghum finger millet. Mysore University; 1976.

30. Bradford MM. A rapid and sensitive method for the quantitation of microgram quantities of protein utilizing the principle of protein dye binding. Anal Biochem. 1976; 72:248-54.

31. Hammerschmidt R, Nuckles EM, Kuc J. Association of enhanced peroxidase activity with induced systemic resistance of cucumber to Colletotrichum lagenarium. Physiol Mol Plant Pathol. 1982; 20:7382.

32. Plewa MJ, Smith SR, Wagner ED. Diethyldithiocarbamate suppresses the plant activation of aromatic amines into mutagens by inhibiting tobacco cell peroxidase. Mutat Res. 1991; 247:57-64.

33. Borthakur $\mathrm{AB}$, Bhat $\mathrm{B}$, Ramasoss CS. The positional specifications of the oxygenation of linolenic acid catalyzed two forms of lipoxgenase isolated from Bengal gram (Cicer arietinum). J Biosci. 1987; 11:257-63.

34. Axelrod B, Cheesbrough TM, Laakso S. Lipoxygenase from soybeans. Methods Enzymol. 1981; 71:441-51.

35. Kulkarni KS, Zala HN, Bosamia TC, Shukla YM, Kumar S, Fougat RS, Patel MS, Narayanan S, Joshi CG. De novo transcriptome sequencing to dissect candidate genes associated with pearl millet-downy mildew (Sclerospora graminicola Sacc.) interaction. Front Plant Sci. 2016; 7:847.

36. Arun-Kumar. Biocontrol of plant diseases: Need to tap the options. J Arid Leg, 2008; 5:99-108.

37. Shetty HS, Kumar VU. Biological control of pearl millet downy mildew: present status and future prospects. In: Upadhyay R, Mukerji $\mathrm{KG}$, Chamola BP, editiors. Biocontrol potential and its exploitation in sustainable agriculture, Germany: Springer Verlag; 2000, Vol I. p. 251-265. 
38. Sriram S, Manasa SB, Savitha MJ. Potential use of elicitors from Trichoderma in induced systemic resistance for the management of Phytophthora capsici in red pepper. J Biol Control. 2009; 23(4):449456.

39. Reimers PJ, Guo A, Leach JE. Increased activity of a cationic peroxidase associated with an incompatible interaction between Xanthomonas oryzae pv. Oryzae and rice. Plant Physiol. 1992; 99:1044-50.

40. Young SA, Guo A, Guikema JA, White FF, Leach JE. Rice cationic peroxidase accumulates in xylem vessels during incompatible interactions with Xanthomonas oryzae pv. oryzae. Plant Physiol. 1995; 107:1333-41.

41. Pushpalatha HG, Sudisha J, Geetha NP, Amruthesh KN, Shetty HS. Thiamine seed treatment enhances LOX expression, promotes growth and induces downy mildew disease resistance in pearl millet. Bio Plant. 2011; 55:522-7.

\section{How to cite this article:}

Nandini B, Hariprasad P, Prakash HS, Geetha N. Trichoderma oligosaccharides priming mediates resistance responses in pearl millet against downy mildew pathogen. J App Biol Biotech. 2017; 5 (02): 097-103. 